Article

\title{
Syngas Biomethanation in a Semi-Continuous Reverse Membrane Bioreactor (RMBR)
}

\author{
Supansa Y. Westman *, Konstantinos Chandolias and Mohammad J. Taherzadeh \\ Swedish Centre for Resource Recovery, University of Borås, Borås 50190, Sweden; \\ konstantinos.chandolias@hb.se (K.C.); mohammad.taherzadeh@hb.se (M.J.T.) \\ * Correspondence: Supansa.westman@gmail.com; Tel.: +46-70-487-7100
}

Academic Editor: Thaddeus Ezeji

Received: 22 January 2016; Accepted: 21 March 2016; Published: 25 March 2016

\begin{abstract}
Syngas biomethanation is a potent bio-conversion route, utilizing microorganisms to assimilate intermediate gases to produce methane. However, since methanogens have a long doubling time, the reactor works best at a low dilution rate; otherwise, the cells can be washed out during the continuous fermentation process. In this study, the performance of a practical reverse membrane bioreactor (RMBR) with high cell density for rapid syngas biomethanation as well as a co-substrate of syngas and organic substances was examined in a long-term fermentation process of 154 days and compared with the reactors of the free cells (FCBR). The RMBR reached maximum capacities of $\mathrm{H}_{2}, \mathrm{CO}$, and $\mathrm{CO}_{2}$ conversion of 7.0,15.2, and $4.0 \mathrm{mmol} / \mathrm{L}_{\text {reactor }}$.day, respectively, at the organic loading rate of $3.40 \mathrm{gCOD} / \mathrm{L}$.day. The highest methane production rate from the RMBR was $186.0 \mathrm{~mL} / \mathrm{L}_{\text {reactor }}$.day

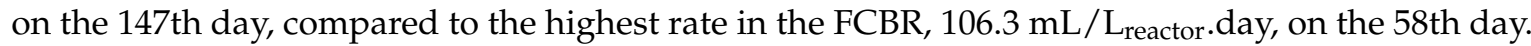
The RMBR had the ability to maintain a high methanation capacity by retaining the microbial cells, which were at a high risk for cell wash out. Consequently, the system was able to convert more syngas simultaneously with the organic compounds into methane compared to the FCBR.
\end{abstract}

Keywords: syngas fermentation; methane production; semi-continuous process; reverse membrane bioreactor; co-substrate; cell retention

\section{Introduction}

Biogas is a renewable energy source with several applications in heating, cooking, or electricity production. Biogas mainly consists of methane and carbon dioxide but may also contain minor impurities of other components [1]. It can also be upgraded to about $97 \%$ biomethane, which is used as a popular renewable form of energy such as car fuel.

Biogas or biomethane can be produced from waste resources that can be classified as easily degradable, difficult to degrade, and non-degradable wastes. To obtain biogas from easily degradable wastes such as food wastes, a biochemical approach called anaerobic digestion process is traditionally employed. In this process, complex polymers of organic substances are degraded easily by microorganisms through the different steps of the anaerobic fermentation process [2]. In the same way, difficult to degrade materials such as lignocelluloses from crop residues and agricultural residues can also be converted into methane by the performance of microorganisms in the anaerobic digestion process. However, the recalcitrance of these difficult to degrade biomass sources, such as the coverage of lignin or the crystallinity of cellulose, limits the access of the microorganisms and enzymes for efficient digestion [3]. The hydrolysis rate can be accelerated by pretreating the substrate with chemical, physical, or biological processes before feeding the substrate to the digester [4]. Nevertheless, the pre-treatment process has been found to be an expensive and rate limiting factor [5]. Thus, the biochemical process may face challenges in converting difficult to degrade wastes into methane. Non-degradable materials such as lignin or plastic wastes cannot be decomposed by microorganisms 
in an anaerobic digestion process. Consequently, it is common to incinerate this category of waste to energy.

On the other hand, it is possible to convert non-degradable wastes and lignocelluloses to biofuels via gasification to syngas and the fermentation routes. The biomass is first gasified into a gas mixture called syngas or synthesis gas. Syngas contains primarily $\mathrm{CO}, \mathrm{H}_{2}$, and $\mathrm{CO}_{2}$. The syngas can be upgraded by methanization, either by using chemical catalysts (e.g., Fischer-Tropsch Synthesis) or through fermentation with microbial catalysts. The fermentation process offers several benefits over the chemical catalytic process, such as a more specific process, higher yields, lower energy consumption, being environmentally friendly, and having better robustness [6,7]. Syngas fermentation for methane production, i.e., syngas biomethanation, is a relatively new technology and a good alternative to the first-generation biofuel.

The biomethanation of the syngas by microorganisms can be performed in two pathways [8]. The first one utilizes an acetate pathway as a methane precursor (Reactions 1 and 2). Acetobacterium woodii and Enbacterium limosum, for example, are microbial cells that perform this reaction. Thereafter, methanogenic microorganisms such as Methanosarcina barkeri convert acetate into methane (Reaction 3):

$$
\begin{gathered}
2 \mathrm{CO}_{2}+4 \mathrm{H}_{2} \rightarrow \mathrm{CH}_{3} \mathrm{COOH}+2 \mathrm{H}_{2} \mathrm{O} \\
4 \mathrm{CO}_{2}+\mathrm{H}_{2} \mathrm{O} \rightarrow \mathrm{CH}_{3} \mathrm{COOH}+2 \mathrm{CO}_{2} \\
\mathrm{CH}_{3} \mathrm{COOH} \rightarrow \mathrm{CH}_{4}+\mathrm{CO}_{2}
\end{gathered}
$$$$
\text { Reaction } 1
$$$$
\text { Reaction } 2
$$

Reaction 3

The other pathway utilizes the $\mathrm{H}_{2} / \mathrm{CO}_{2}$ pathway. $\mathrm{CO}$ can be converted into $\mathrm{CO}_{2}$ (Reaction 4) by microorganisms, for example, Methanothermobacter thermoautotrophicus and Clostridium thermoaceticum [9]. The $\mathrm{H}_{2}$ and $\mathrm{CO}_{2}$ produced by reaction 4 and initially present in the syngas are converted into methane by some microorganisms such as Methanosarcina formicicum (Reaction 5) [8]:

$$
\begin{array}{cr}
\mathrm{CO}+\mathrm{H}_{2} \mathrm{O} \rightarrow \mathrm{CO}_{2}+\mathrm{H}_{2} & \text { Reaction } 4 \\
4 \mathrm{H}_{2}+\mathrm{CO}_{2} \rightarrow \mathrm{CH}_{4}+\mathrm{H}_{2} \mathrm{O} & \text { Reaction 5 }
\end{array}
$$

However, these microbial groups, especially, methane-producing microorganisms, require a long retention time in the digester, since their growth rate is very low. In addition, they are very sensitive to harsh conditions; hence, the cells can easily be washed out from the digester at high dilution rates in a continuous process. For these reasons, the population size of the microbial cells is easily reduced, resulting in a decreased methane production and low process efficiency. Moreover, fermentation processes with low cell density need long start-up periods, and larger digesters are required for proper function, which means that the capital cost is high. Retaining the microbial cells inside a compact bioreactor with a low chance of bio-fouling and abraded microorganisms might be a solution to overcome these problems.

Different bioreactor designs have been developed in order to enhance the process efficiency of the syngas fermentation [10-15]. For instance, continuous stirred tank reactors (CSTR) have been frequently employed for syngas fermentation. A high speed of agitation in the CSTR can be used to enhance the mass transfer efficiency. However, it has been observed to result in high shear stress on the cells and high-energy consumption [16,17].

In another study, a bioreactor for syngas fermentation was connected to a hollow fiber membrane module [16]. The system enhanced the gas-liquid mass transfer as well as allowed the microbial cells to be attached on the membrane layer [16]. However, a long start-up period for cell attachment to the outer membrane layer was crucial. The same authors also developed a novel bioreactor configuration, called a monolithic biofilm reactor, for the same purpose. The results revealed that the performance of the syngas fermentation process depended not only on the mass transfer efficiency, but the low efficiency was also related to bio-fouling and abrading of the microbial cells attached to the channel of the monolithic wall [18]. Liu et al. [19] used the membrane module for the cell retention system in 
continuous syngas fermentation for ethanol production. However, cell wash out still occurred, which was one of the reasons for low product formation.

From these results and the nature of methane-producing microorganisms, retaining a high microbial cell density in the bioreactor and preventing cell washout during the syngas continuous fermentation processes are important aspects to keep the process stable and increase the methane productivity [15].

The reverse membrane bioreactor (RMBR) is a configuration of a bioreactor for methane production. The RMBR system can be defined as a process that employs a fixed microbial growth system with the use of membranes. This bioreactor system was designed to enclose the cells completely in the permeable membrane filter, while substrates in the surrounding liquid are able to diffuse through the membrane to the cells. The fermentation products can thereafter diffuse out to the surrounding solution. Additional equipment for the cell recycle system is not necessary for this kind of process. This technique provided a high cell density; consequently, the process efficiency and productivity of the anaerobic digestion process for methane production were improved [20-23].

The current work focuses on applying the RMBR for syngas biomethanation under anaerobic semi-continuous mode in order to retain a high cell loading and consequently, improve the process performance. The simultaneous fermentation of syngas and organic compounds was also investigated. The performance of the system was evaluated under thermophilic anaerobic conditions and compared to the conventional system of free cells bioreactor (FCBR) under the same conditions.

\section{Materials and Methods}

\subsection{Anaerobic Culture, Medium, and Raw Syngas}

An anaerobic culture was obtained from a 3000- $\mathrm{m}^{3}$ municipal solid waste digester, operating under thermophilic $\left(55^{\circ} \mathrm{C}\right)$ conditions (Borås Energy and Environment $\mathrm{AB}$, Borås, Sweden). The inoculum was incubated at $55{ }^{\circ} \mathrm{C}$ for 3 days to keep the bacteria active while consuming the carbon source provided by the inoculum. After incubation, the inoculum was filtered through a sieve (1-mm pore size) to remove the large particles. The digesting sludge was then centrifuged at $31,000 \times g$ for $15 \mathrm{~min}$ to separate the solid inoculum (85\% Total solid (TS)) and the microorganisms, which were loaded into membrane sachets (Section 2.2). The synthetic medium solution contained acetate, propionate, butyrate with COD strength of $6.72 \mathrm{gCOD} / \mathrm{L}$, and a vitamin solution (basal medium) with COD strength of $3.34 \mathrm{gCOD} / \mathrm{L}$ at a ratio of 3:1:1:1 [24]. The medium solution was buffered to $\mathrm{pH} 7.0 \pm 0.2$ with $\mathrm{NaHCO}_{3}$ [25]. The artificial syngas containing $\mathrm{CO}(55 \% \mathrm{~mol}), \mathrm{H}_{2}(20 \% \mathrm{~mol})$, and $\mathrm{CO}_{2}(10 \% \mathrm{~mol})[11]$ was provided by AGA gas AB (Borås, Sweden).

\subsection{Cell Containment Procedure for the RMBR Configuration}

The microbial cell encasement was performed following a previously described method [23]. Flat plain hydrophilic PVDF (polyvinylidene fluoride, Durapore ${ }^{\circledR}$ ) membranes (Merch Millipore Ltd., Cork, Ireland) with a pore size, thickness, and diameter of $0.1 \mu \mathrm{m}, 125 \mu \mathrm{m}$, and $90 \mathrm{~mm}$, respectively, were used as supporting materials. The main physicochemical characteristics of the membranes are: air flow rate of $0.15 \mathrm{~L} / \mathrm{min} . \mathrm{cm}^{2}, 0.5 \%$ gravimetric extractables, $70 \%$ porosity, and water flow rate greater than $0.33 \mathrm{~mL} / \mathrm{min} . \mathrm{cm}^{2}$. The membranes were cut into rectangular shapes of $6 \times 6 \mathrm{~cm}^{2}$ and folded to create membrane pockets of $3 \times 6 \mathrm{~cm}^{2}$. They were then heat-sealed (HPL 450 AS, Hawo, Obrigheim, Germany) on three sides with heating and cooling times of 4.5 and $4.5 \mathrm{~s}$, leaving one side open for the insertion of the inoculum. Solid sludge inoculum ( $3 \mathrm{~g}$ per sachet) was then injected carefully into the synthetic membrane pockets, and the fourth side was subsequently sealed. The sachets containing the inoculum were used immediately for biomethanation of syngas. 


\subsection{Reactor Set up for Semi-Continuous Operation}

The schematic illustration of the RMBR system is shown in Figure 1. The reactors used were serum glass bottles with 600-mL working volume, closed with rubber seals and an outlet for the biogas. The RMBR contained 15 sachets of encased inoculum (a total of $45 \mathrm{~g}$ ) and $475 \mathrm{~mL}$ of synthetic medium. In parallel, the same amount of solid inoculum and medium was used in a reference reactor of free cells (FCBR) and performed under the same process conditions. The thermophilic temperature was maintained at $55 \pm 1{ }^{\circ} \mathrm{C}$ throughout the process by placing the reactors in a water bath. The syngas amount was gradually increased by flushing fresh syngas at different gas pressures. Simultaneously, the OLR was gradually increased by increasing the concentrations of the medium fed (Table 1). During the fermentation process, the syngas was continuously bubbled through the reactors, from the bottom rising up to the top of the reactors, from where it was circulated to the bottom at different flow rates. Each co-substrate loading rate and gas circulation rate was maintained for different experiments (different periods of time), giving a total digestion process of 154 days.

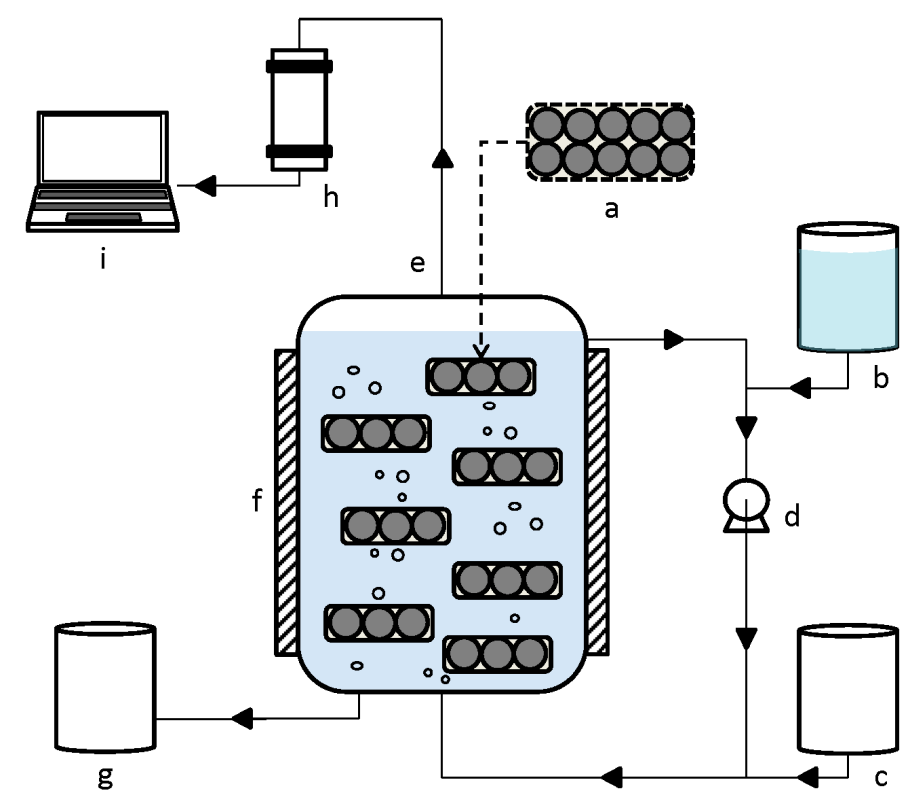

Figure 1. Schematic illustration of the reverse membrane bioreactor (RMBR) in the semi-continuous biomethanation process of syngas and organic substances. (a) Digesting sludge encased in PVDF membrane; (b) Organic and nutrient inlet; (c) Syngas inlet; (d) Peristaltic pump; (e) Product outlet; (f) Warm water bath; (g) Effluent outlet; (h) Gas sampling; and (i) Data analysis.

Table 1. Parameter profiles during the simultaneous semi-continuous biomethanation process.

\begin{tabular}{cccccc}
\hline \multirow{2}{*}{ Periods (Days) } & $\begin{array}{c}\text { Gas Circulation } \\
\text { Rate (mL/min) }\end{array}$ & $\begin{array}{c}\text { Organic Loading } \\
(\mathbf{g C O D / L} \text { reactor.day) }\end{array}$ & \multicolumn{3}{c}{ Syngas Amounts (mmol/L $\mathbf{L}_{\text {reactor.day) }}$} \\
\cline { 4 - 6 } & & 0.02 & $\mathbf{H}_{\mathbf{2}}$ & $\mathbf{C O}$ & $\mathbf{C O}_{\mathbf{2}}$ \\
\hline I (0-16) & 100 & 0.02 & 1.1 & 3.1 & 1.6 \\
II (17-36) & 200 & 0.02 & 2.2 & 6.1 & 1.7 \\
III (37-58) & 200 & 0.43 & 1.8 & 7.7 & 1.6 \\
IV (59-87) & 300 & 0.86 & 1.7 & 4.0 & 0.7 \\
V (88-126) & 300 & 1.70 & 3.8 & 4.7 & 1.0 \\
VI (127-147) & 300 & 3.40 & 7.0 & 9.4 & 1.9 \\
VII (148-154) & 300 & &
\end{tabular}

The parameter profiles are shown in Table 1. At the beginning of the digestion (periods I, II, and III), the syngas amount added was gradually increased. The OLR was kept relatively low, according to a very low organic content in the basal medium that was used as the vitamins and 
minerals solution during these periods. This was done in order to allow the anaerobic culture to adapt to the environment with a low risk of cell washout and to investigate the ability of both systems to result in pure syngas fermentation. Then, from period IV to VII, the organic compounds containing acetate, propionate, and butyrate were added simultaneously with syngas. The OLR was doubled in order to investigate the efficiency of the systems under the harsh conditions at a shorter retention time.

For the adjustment of the syngas compounds inside the reactor, syngas was placed in a 1-L gas sampling bag and then the gas was fed to the reactor by a peristaltic pump. Inside the sampling bag, there was a known syngas volume that could be adjusted, and the content of each compound was analysed. Then, the gas was placed inside the reactor (with a known headspace), and the percentage of each syngas component was measured again. The ideal gas law was used for calculating the mole number:

$\mathrm{PV}=\mathrm{nRT}$, where:

P: $1 \mathrm{~atm}$, adjusted with a needle after the syngas feeding; V: the headspace of the reactor (stable); R: the ideal gas law constant; $T$ : the temperature of the reactor; $n$ : the unknown mole value that was calculated.

\subsection{Analytical Methods}

The composition of the gas samples (methane, hydrogen, carbon monoxide, and carbon dioxide) was measured regularly, using a gas chromatograph (Perkin-Elmer, Norwalk, CT, USA), equipped with a packed column (CarboxenTM 1000, SUPELCO, $6^{\prime} \times 1.8^{\prime \prime}$ OD, 60/80 Mesh, Shelton, CT, USA) and a thermal conductivity detector (Perkin-Elmer) with an injection temperature of $200{ }^{\circ} \mathrm{C}$. The carrier gas was nitrogen, with a flow rate of $30 \mathrm{~mL} / \mathrm{min}$ at $75^{\circ} \mathrm{C}$. A $250-\mu \mathrm{L}$ gas tight syringe (VICI, Precision Sampling Inc., Baton Rouge, LA, USA) was used for the gas sampling. The obtained peak area was compared with a standard gas, analyzed under the same conditions (STP, $273.15^{\circ} \mathrm{K}$ and $101.325 \mathrm{kPa}$ ). The volatile fatty acids (VFAs) were analyzed using a gas chromatograph (Auto System, Perkin-Elmer) equipped with a capillary column (Zebron ZB-WAXplus, Polyethylen glycol (PEG), $30 \mathrm{~m} \times 0.25 \mathrm{~mm} \times 0.25 \mu \mathrm{m}$, Shelton, CT, USA) and a flame ionized detector (Perkin-Elmer) with an injection and detection temperature of 250 and $300^{\circ} \mathrm{C}$, respectively. The carrier gas was nitrogen, with a flow rate of $2 \mathrm{~mL} / \mathrm{min}$ at a pressure of $20 \mathrm{psi}$. The experiment was performed in duplicate, and the results were presented as the average \pm standard deviation.

\section{Results and Discussion}

Syngas biomethanation is a potent bio-conversion route, utilizing microorganisms to assimilate intermediate gases to produce methane. However, the cell density in continuous bioreactor operations plays an important role in the process efficiency. In this work, a novel application of the RMBR was investigated: rapid syngas biomethanation in a semi-continuous operation at high cell loading. The performance of the RMBR was compared to the performance of a reactor with free cells (FCBR) under otherwise identical conditions.

During the semi-continuous biomethanation process of 154 days, the performance of the RMBR and the FCBR was investigated under seven experimental conditions (seven periods). The conditions of each period are presented in Table 1.

\subsection{Methane Production}

Figure 2 and Table 2 show the trend of the methane production throughout the anaerobic process. Methane was produced from mainly pure syngas at the beginning of the process (Periods I-III), to thereafter be produced also from the co-substrates until the last day. The methane formed from these substrates was likely made by the acetic cleavage of acetate and the reduction of carbon dioxide. The microorganisms assimilating these substrates are mainly hydrogenotrophic methanogens and acetotrophic methanogens. It was observed that the methane production increased with the increasing concentration of gaseous and organic substrates fed, until the maximum conversion capacity was 
reached and the production decreased. This shows that the metabolism of the microorganisms occurred as expected.

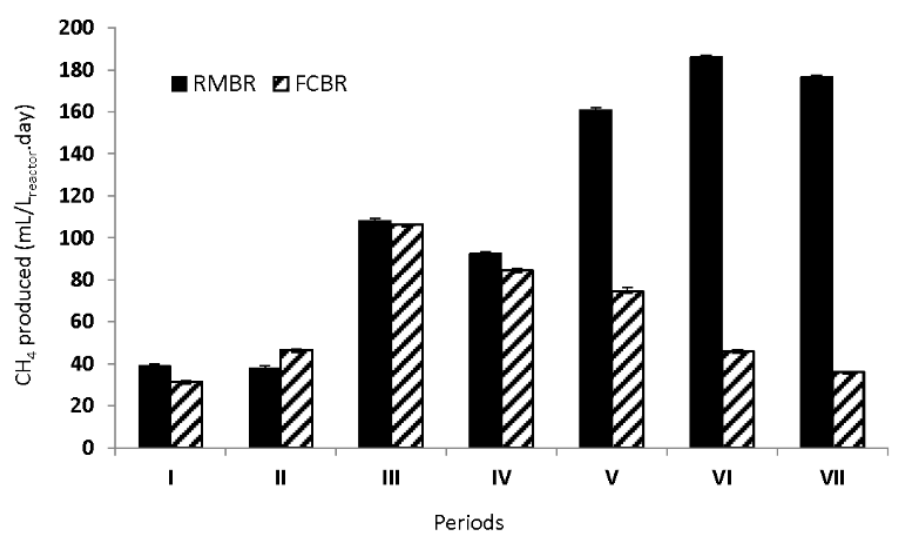

Figure 2. Comparison of the methane production in the reverse membrane bioreactor (RMBR) system and the free cell bioreactor (FCBR) during the semi-continuous biomethanation of syngas and organic substances.

Table 2. Investigated parameters during the semi-continuous biomethanation process of the co-substrates.

\begin{tabular}{ccccc}
\hline \multirow{2}{*}{ Periods } & \multicolumn{2}{c}{ Methane Production $\left(\mathrm{mL} / \mathbf{L}_{\text {reactor.day) }}\right.$} & \multicolumn{2}{c}{ Total VFA (g/L) } \\
\cline { 2 - 5 } & RMBR & FCBR $^{* *}$ & RMBR $^{*}$ & FCBR $^{* *}$ \\
\hline I & $39.1 \pm 0.4$ & $31.4 \pm 0.5$ & $0.4 \pm 0.0$ & $0.5 \pm 0.0$ \\
II & $38.0 \pm 0.7$ & $46.4 \pm 0.5$ & $0.4 \pm 0.0$ & $0.5 \pm 0.0$ \\
III & $108.9 \pm 0.2$ & $106.3 \pm 0.2$ & $0.4 \pm 0.0$ & $0.5 \pm 0.0$ \\
IV & $92.5 \pm 1.5$ & $84.4 \pm 1.2$ & $0.8 \pm 0.3$ & $1.0 \pm 0.3$ \\
V & $160.8 \pm 1.1$ & $74.5 \pm 1.7$ & $0.4 \pm 0.3$ & $1.2 \pm 0.7$ \\
VI & $186.0 \pm 1.3$ & $46.0 \pm 0.6$ & $4.4 \pm 3.5$ & $4.0 \pm 3.0$ \\
VII & $176.5 \pm 0.3$ & $36.2 \pm 0.1$ & $7.8 \pm 0.8$ & $9.4 \pm 0.5$ \\
\hline
\end{tabular}

* The reverse membrane bioreactor. ${ }^{* *}$ The free cells bioreactor.

In the beginning of the experiment, a total pure syngas amount of $5.8 \mathrm{mmol} / \mathrm{L}$.day was added to the reactors. The amount was thereafter gradually increased throughout the operation of the reactors (Table 1). The basal medium with an organic content was fed at a low rate of 0.02 gCOD/L.day during the periods I, II, and III, and a similar methane production was observed in both reactors. The methane amount produced in the RMBR and the FCBR during these periods ranged between 38.0-108.9 mL/L.day and 31.4-106.3 mL/L.day, respectively. These results show that under a low risk of cell wash-out condition, the encased microorganisms in the RMBR displayed a similar methane production performance from syngas as the free microorganisms in the FCBR. The results also indicate that using PVDF membranes as a cell supporting material in the current reactor setup was not a major issue for the continuous syngas fermentation when it came to diffusion limitations. In addition, due to the practical design of the RMBR, the problematic issues of cell clogging and cell abrading are likely less severe.

During the periods IV, V, and VI, the organic compounds were introduced to both the reactors while the syngas amount added to the systems was decreased slightly in order to maintain a mild condition for microbial adaptation. From these experiments, the microorganisms retained in the RMBR could assimilate the co-substrate perfectly with maintained efficient performance, resulting in a corresponding increase of the methane production (Table 2 and Figure 2). The maximum methane productivity of the RMBR during these periods was 92.5, 160.8, and $186.0 \mathrm{~mL} / \mathrm{L}$.day, respectively. On the other hand, the wash-out of the microbial cells from the FCBR was clearly occurring during 
these periods, resulting in a substantially lower methane production from the FCBR than the RMBR during the periods V and VI (74.5 and $46.0 \mathrm{~mL} / \mathrm{L}$.day). In the RMBR, the microbial cells were still enclosed completely in the membrane sachets, and cell abrading was not visually occurring.

A better cell retention performance of the RMBR for syngas biomethanation in a semi-continuous process was clearly shown during period VII, when a higher syngas amount ( $26.2 \mathrm{mmol} /$ L.day) was fed to both the reactors, while the organic loading was doubled in comparison to period VI. The methane production in the RMBR was higher than the production in the FCBR (176.5 and $36.2 \mathrm{~mL} / \mathrm{L}$. day, respectively). These results indicate that the RMBR had the ability to maintain a high methanation capacity, by retaining the microbial cells under the high risk of cell-wash out condition. Consequently, the system was able to convert more substrates into methane than the one with the free cells. This result stresses the importance of cell-retention inside anaerobic digestion as shown in other studies in which biofilm was used for high cell-density. However, with the method of cell-enclosure in the membranes, there is no danger of cell-detachment in contrast with the use of biofilm [26].

In the last period, the higher co-substrate concentration was fed to the systems in order to investigate if the product profiles changed. The results showed that the methane production in both the reactors was maintained at a low level, observed as a lower utilization of $\mathrm{H}_{2}$ and $\mathrm{CO}$ (Figure 3a,b) and higher concentration of VFAs (Table 2). The co-substrate was not completely converted by the microbial cells in this period. This result indicates that the maximum conversion capacity of the systems had been reached. The lower methane production was probably because of the inhibitory effect of a high hydrogen partial pressure from the syngas, as well as the accumulation of the volatile fatty acids from the organic substances [2]. However, a higher amount of methane was still formed in the RMBR compared to the FCBR. This is an effect of the higher amount of microbial cells retained in the RMBR, still able to consume the co-substrates and convert them into methane.
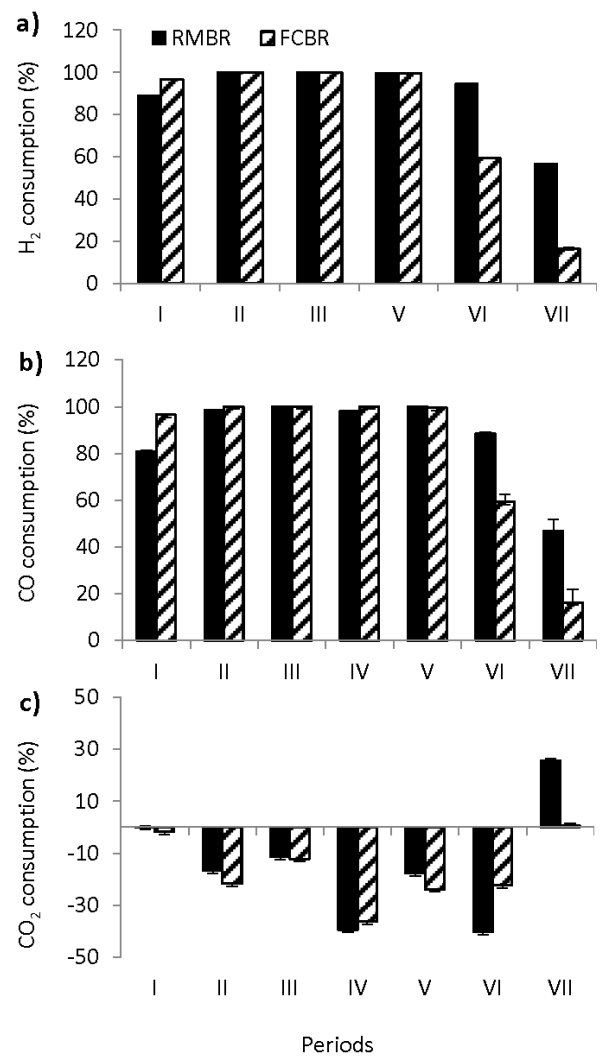

Figure 3. Comparison of the performance of the reverse membrane bioreactor (RMBR) system and the free cell bioreactor (FCBR) during the semi-continuous biomethanation of syngas and organic substances. The utilization of (a) Hydrogen; (b) Carbon monoxide; and (c) Carbon dioxide. 
The above results indicate that during 154 days of syngas biomethanation, the RMBR system was an efficient and practical process in retaining the microbial cells, resulting in a high methane production under a semi-continuous process condition.

\subsection{Syngas Utilization Efficiency}

Periods I, II, and III were designed to allow the microbial cells to adapt to the environmental conditions in the beginning of the experiment. The artificial syngas fed was gradually increased, while the organic loading rate was controlled at a very low level (0.02 gCOD/L.day). The medium used only contained nutrients and vitamins during these periods. The flow rate of the gas recirculation was $100 \mathrm{~mL} / \mathrm{min}$ in the first experiment, and thereafter increased to $200 \mathrm{~mL} / \mathrm{min}$ during periods II and III in order to test the performances of the systems with shortened gas retention time. Figure 3 and Table 3 present the percentage of gas utilization during the semi-continuous syngas fermentation process of 154 days.

Table 3. Investigated parameters during the semi-continuous biomethanation process of the co-substrates.

\begin{tabular}{ccccccc}
\hline \multirow{2}{*}{ Periods } & \multicolumn{4}{c}{ Syngas Component Utilization (\%) RMBR * } & \multicolumn{4}{c}{ Syngas Component Utilization (\%) FCBR ** } \\
\cline { 2 - 6 } & $\mathbf{H}_{\mathbf{2}}$ & $\mathbf{C O}$ & $\mathbf{C O}_{\mathbf{2}}$ & $\mathbf{H}_{\mathbf{2}}$ & $\mathbf{C O}$ & $\mathbf{C O}_{\mathbf{2}}$ \\
\hline I & $88.9 \pm 0.0$ & $80.8 \pm 0.4$ & $-0.0 \pm 0.5$ & $96.5 \pm 0.0$ & $87.2 \pm 0.2$ & $-1.7 \pm 0.0$ \\
II & $100.0 \pm 0.0$ & $98.7 \pm 0.0$ & $-16.6 \pm 0.1$ & $100.0 \pm 0.0$ & $99.5 \pm 0.0$ & $-21.7 \pm 0.0$ \\
III & $100.0 \pm 0.0$ & $100.0 \pm 0.0$ & $-11.4 \pm 0.2$ & $100.0 \pm 0.0$ & $100.0 \pm 0.0$ & $-12.2 \pm 0.1$ \\
IV & $100.0 \pm 0.0$ & $98.2 \pm 0.1$ & $-39.3 \pm 0.1$ & $100.0 \pm 0.0$ & $99.8 \pm 0.0$ & $-36.3 \pm 0.0$ \\
V & $99.7 \pm 0.0$ & $100.0 \pm 0.0$ & $-17.6 \pm 0.2$ & $99.5 \pm 0.0$ & $100.0 \pm 0.0$ & $-23.8 \pm 0.2$ \\
VI & $94.7 \pm 0.2$ & $88.4 \pm 0.7$ & $-40.3 \pm 0.1$ & $59.3 \pm 0.6$ & $42.3 \pm 3.3$ & $-22.3 \pm 0.1$ \\
VII & $56.6 \pm 0.2$ & $46.8 \pm 4.9$ & $25.6 \pm 0.7$ & $16.4 \pm 0.3$ & $38.9 \pm 5.7$ & $0.8 \pm 0.7$ \\
\hline \multicolumn{7}{r}{ * The reverse membrane bioreactor ** The free cells bioreactor. }
\end{tabular}

* The reverse membrane bioreactor. ${ }^{* *}$ The free cells bioreactor.

The amount of $\mathrm{H}_{2}$ in both the reactors remained at a very low level even when the $\mathrm{H}_{2}$ (syngas) fed was increased from 1.1 to $2.8 \mathrm{mmol} / \mathrm{L}$.day, and the gas circulation rate was increased from 100 to $200 \mathrm{~mL} / \mathrm{min}$. The percentage of $\mathrm{H}_{2}$ consumed in the RMBR and the FCBR was close to 100 percent. This shows that the microbial cells in both the RMBR and the FCBR could convert the $\mathrm{H}_{2}$ easily within 1 day. Similar to the conversion of $\mathrm{H}_{2}$ in both the reactors during these periods, the microorganisms also converted all the $\mathrm{CO}$, without any observed negative effects. The $\mathrm{CO}$ in the gas fed was increased from 3.1 to $7.7 \mathrm{mmol} / \mathrm{L}$.day (Table 1), and it was utilized by the microbial cells in both the systems at almost the same rate (about 100 percent). The $\mathrm{CO}_{2}$ amounts showed a different trend from the other gases. It increased during the first 3 days, and then stayed stable throughout periods I-III. It was observed that the $\mathrm{CO}_{2}$ amounts in both the reactors increased rather than decreased during these periods (a $\mathrm{CO}_{2}$ amount of 1.6-1.7 mmol/L.day was present in the syngas fed). This trend indicated that the microbial cells in both the reactors had performed as expected, with the $\mathrm{CO}_{2}$ being both produced and consumed during the fermentations. Thus, even though $\mathrm{CO}_{2}$ was supplemented together with the other compounds in the syngas, $\mathrm{CO}_{2}$ was also produced, leading to a stable amount of $\mathrm{CO}_{2}$ (Figure $3 \mathrm{c}$ ). The most interesting conclusion that can be drawn from the results of these periods is that the gases transfer through the PVDF membrane used, as the cell encasing material was not a limiting factor during the semi-continuous fermentation process, since the amount of the different components of the syngas were at similar levels as in the free cell system. The encased cells in the RMBR could assimilate the syngas continuously for product formation.

During periods IV and V, the gas circulation rate was increased to $300 \mathrm{~mL} / \mathrm{min}$, reducing the gas retention time in the systems. The syngas amount was decreased slightly while higher organic loading rates with a medium containing acetic, propionic, and butyric acid was introduced. The results showed that the syngas conversion performance of both the reactors was maintained during the simultaneous 
co-substrate fermentation. The microorganisms in both of the systems utilized almost 100 percent of the $\mathrm{H}_{2}$ and $\mathrm{CO}$. However, $\mathrm{CO}_{2}$ started accumulating during these periods, indicating that the microbial cells decomposed the organic acids.

During the last two periods, VI and VII, a higher concentration of co-substrates was provided to the reactors. The results showed that the syngas utilization showed a decreasing trend in both the reactors, despite a higher concentration being added to the reactors during period VII (Table 1). The higher gas amounts, especially of $\mathrm{H}_{2}$, in the systems probably increased the partial pressure, thereby leading to a higher $\mathrm{pH}$ of the liquid solution (Figure $4 \mathrm{~b}$ ). Furthermore, additional organic substances, which resulted in the accumulated VFA, were present during these periods (Figure 4a). This resulted in a decreased performance of the microorganisms in the reactors. However, the RMBR still showed a better ability to utilize the high concentration of co-substrates than the FCBR during these periods, shown by a higher percentage of $\mathrm{H}_{2}$ and $\mathrm{CO}$ utilization (Table 2). The percentage of $\mathrm{H}_{2}$ utilization in the RMBR and the FCBR from period VI was 94.7 and 59.3, respectively. The CO utilization in the RMBR and the FCBR was 88.4 and 42.3 percent, respectively. $\mathrm{CO}_{2}$ was accumulated, resulting in negative utilization values of -40.3 and -22.3 percent, respectively. These results revealed that the RMBR had a better capacity than the conventional system of the FCBR to convert higher syngas and co-substrate concentrations in a semi-continuous fermentation process. However, a positive $\mathrm{CO}_{2}$ utilization in both the reactors was observed in period VII. This means that $\mathrm{CO}_{2}$ was consumed at a higher rate than it was produced. In general, $\mathrm{CO}_{2}$ is produced during the anaerobic digestion of organic compounds. In period VII, the VFAs were accumulated, meaning that the organic substances were not much used. This leads to less $\mathrm{CO}_{2}$ production in both the RMBR and FCBR. Although a higher amount of $\mathrm{CO}_{2}$ was fed to the reactors (Table 1), $\mathrm{CO}_{2}$ was likely utilized by the microbial cells, thus resulting in a positive $\mathrm{CO}_{2}$ utilization. It can be concluded that retaining the microorganisms in the RMBR was a successful technique for improving the syngas biomethanation in the long-term fermentation process. Encased microbial cells in the RMBR showed a similar performance to assimilate the syngas in a semi-continuous biomethanation process as the system with the free cells at a low organic loading rate. Moreover, when higher syngas and organic loading rates were applied, a higher process efficiency of the RMBR, compared to the FCBR, was observed.
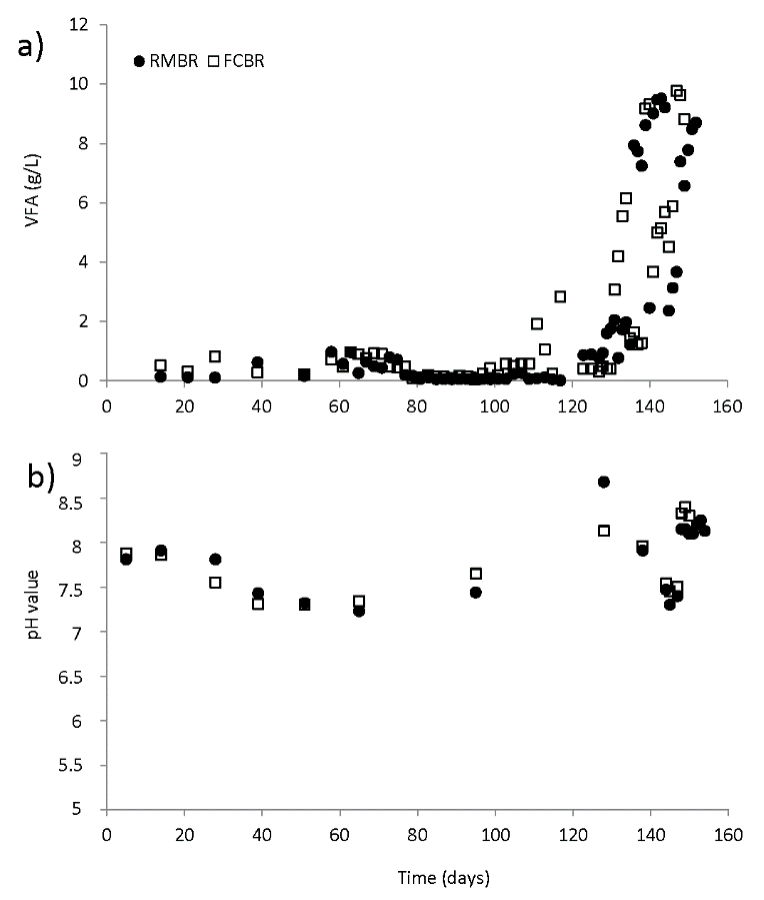

Figure 4. Accumulation of organic acids and $\mathrm{pH}$ during the semi-continuous biomethanation of co-substrates. (a) Volatile fatty acids; (b) $\mathrm{pH}$. 


\subsection{Volatile Fatty Acids and $p H$ Profile}

In this work, the performance of the bioreactors with cells degrading a mixture of two substrates in a semi-continuous process was investigated. Organic acids, including acetic, propionic, and butyric acid, were used as co-substrates to the syngas in the fermentations. The organic loading rate (OLR), in the form of the organic acids fed, was gradually increased in both the systems. The data of total volatile fatty acids (VFAs) in the effluents represented the organic acids utilization during the simultaneous fermentation process. The VFA value is also an indicator for monitoring the stability of the anaerobic digestion process [4]. In a previous work, repeated batch syngas biomethanation was examined [27]. All of the medium was removed, and the encased cells were reused in a new batch experiment. In that setup, the inhibiting substances probably disappeared, which is different from the continuous process of the present work, where most of the substrates remained in the reactors. Thus, the trend of the VFA content and the $\mathrm{pH}$ values were investigated in this experiment.

Figure 4 represents the total VFA concentration (a) and the $\mathrm{pH}$ values (b) in the effluents during the semi-continuous fermentation processes in the two investigated cell systems. The VFA amounts in both the reactors were close to zero during the periods I, II, III, and IV, even when the organic loading was increased from 0.02 to $0.43 \mathrm{~g}$ COD/L.day. This indicates that the microorganisms in both the reactors were able to convert the organic substances simultaneously with syngas, without any observed negative effect. However, the $\mathrm{pH}$ value decreased slightly when the organic acids were introduced to the system during these periods. The $\mathrm{pH}$ was in the range of 7.0-7.8, and the changes were not observed to affect the stability of the processes.

A low amount of VFAs in the reactors shows that the microorganisms are coping well with the process conditions. In the anaerobic digestion process, VFAs can be consumed by the methane-producing microorganisms. This reduction of VFAs increases the alkalinity of the surrounding medium. The $\mathrm{pH}$ in the anaerobic digester is significantly affected by the production of VFAs and the $\mathrm{CO}_{2}$ content of the biogas.

In period V (days 88-126), there were substantially lower VFA concentrations measured in the effluent from the RMBR (around $0.2 \mathrm{~g} / \mathrm{L}$ ) compared to the free cell system FCBR (around $0.6 \mathrm{~g} / \mathrm{L}$ ), as the OLR was increased to $0.86 \mathrm{gCOD} / \mathrm{L}$.day. However, the VFAs concentration still remained at a low level during this period. The VFAs concentration in the RMBR was totally consumed. The reason for this fact was probably the high active microbial cell density retained in the RMBR, while the cell wash out was visually occurring from the FCBR. During this experiment, the $\mathrm{pH}$ value of both the reactors started to ramp up slightly. This probably happened because of the high conversion rate of the VFAs to biogas (methane and $\mathrm{CO}_{2}$ ), as well as the additional $\mathrm{CO}_{2}$ fed contained in the syngas (Figure $4 \mathrm{~b}$ ). In particular, the value from the RMBR had lower residual VFAs content than the FCBR. The $\mathrm{pH}$ increased to 8.7 and 8.1 in the RMBR and the FCBR, respectively.

When the concentration of the organic acids and syngas were increased in the last period, the accumulation of the VFAs was even higher, while the $\mathrm{pH}$ dropped slightly. The VFA accumulation in the FCBR increased, reaching a maximum amount of $9.4 \mathrm{~g} / \mathrm{L}$, while the total VFAs in the RMBR were detected at $7.8 \mathrm{~g} / \mathrm{L}$, indicating that the cell encasement in the RMBR helped to maintain a higher ability to degrade the VFAs compared to the FCBR in a semi-continuous fermentation process. However, the recommended VFA concentrations during the anaerobic digestion, without negatively affecting the methane-producing microorganisms in the process, are under $4 \mathrm{~g} / \mathrm{L} \mathrm{[1,2].} \mathrm{At} \mathrm{the} \mathrm{observed} \mathrm{levels} \mathrm{in} \mathrm{the}$ reactors, it was thus clear that the maximum process capacity had been reached in this condition.

These results indicated that the RMBR system performed efficiently during the semi-continuous syngas biomethanation with the addition of organic substances as a co-substrate. Organic acids were degraded simultaneously with the reduction of the syngas until too high amounts of substrates were fed to the systems. 


\section{Conclusions}

The syngas biomethanation under simultaneous semi-continuous fermentation could be enhanced by retaining a high microbial cell density in a reverse membrane bioreactor (RMBR). No cell washout was visually observed from the RMBR during the process, running for 154 days. The performance of the RMBR for the simultaneous fermentation of syngas and the organic compounds was better than the conventional system of free cells (FCBR). The microorganisms in the RMBR were able to convert the syngas simultaneously with organic acids to methane at higher substrate concentrations and productivity than the FCBR system. The RMBR reached maximum capacities of $\mathrm{H}_{2}, \mathrm{CO}$, and $\mathrm{CO}_{2}$ conversion of 7.0,15.2, and $4.0 \mathrm{mmol} / \mathrm{L}$.day, respectively, at the organic loading rate of $3.40 \mathrm{gCOD} / \mathrm{L}$.day. The highest methane production rate from the RMBR was $186.0 \mathrm{~mL} / \mathrm{L}_{\text {reactor.day on }}$

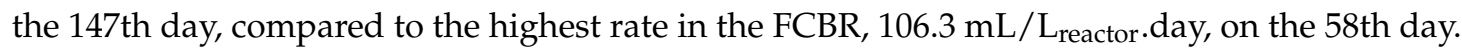

Acknowledgments: This work was financially supported by the Swedish Research Council. The authors would like to thank Johan Westman for the useful discussions.

Author Contributions: All authors contributed to the conception and design of experiments; Supansa Y. Westman and Konstantinos Chandolias performed the experiments and analyzed the data; all authors contributed to writing the paper.

Conflicts of Interest: The authors declare no conflict of interest.

\section{References}

1. Deublein, D.; Steinhauser, A. Biogas from Waste and Renewable Resources; Wiley-VCH Verlag GmbH \& Co.: Weinheim, Germany, 2008; pp. 49-50.

2. Gerardi, M.H. The Microbiology of Anaerobic Digesters; John Wiley \& Sons: Hoboken, NJ, USA, 2003.

3. Nizami, A.-S.; Korres, N.E.; Murphy, J.D. Review of the integrated process for the production of grass biomethane. Environ. Sci. Technol. 2009, 43, 8496-8508. [CrossRef] [PubMed]

4. Santosh, Y.; Sreekrishnan, T.R.; Kohli, S.; Rana, V. Enhancement of biogas production from solid substrates using different techniques-A review. Bioresour. Technol. 2004, 95, 1-10.

5. Daniell, J.; Köpke, M.; Simpson, S. Commercial biomass syngas fermentation. Energies 2012, 5, $5372-5417$. [CrossRef]

6. Mohammadi, M.; Najafpour, G.D.; Younesi, H.; Lahijani, P.; Uzir, M.H.; Mohamed, A.R. Bioconversion of synthesis gas to second generation biofuels: A review. Renew. Sust. Energy Rev. 2011, 15, 4255-4273. [CrossRef]

7. Munasinghe, P.C.; Khanal, S.K. Biomass-derived syngas fermentation into biofuels: Opportunities and challenges. Bioresour. Technol. 2010, 101, 5013-5022. [CrossRef] [PubMed]

8. Kimmel, D.E.; Klasson, K.T.; Clausen, E.C.; Gaddy, J.L. Performance of trickle-bed bioreactors for converting synthesis gas to methane. Appl. Biochem. Micro. 1991, 28-29, 457-469. [CrossRef]

9. Henstra, A.M.; Sipma, J.; Rinzema, A.; Stams, A.J.M. Microbiology of synthesis gas fermentation for biofuel production. Curr. Opin. Biotech. 2007, 18, 200-206. [CrossRef] [PubMed]

10. Klasson, K.T.; Ackerson, M.D.; Clausen, E.C.; Gaddy, J.L. Bioconversion of synthesis gas into liquid or gaseous fuels. Enzym. Microb. Technol. 1992, 14, 602-608. [CrossRef]

11. Klasson, K.T.; Elmore, B.B.; Vega, J.L.; Ackerson, M.D.; Clausen, E.C.; Gaddy, J.L. Biological production of liquid and gaseous fuels from synthesis gas. Appl. Biochem. Biotechnol. 1990, 24-25, 857-873. [CrossRef]

12. Lee, P.-H.; Ni, S.-Q.; Chang, S.-Y.; Sung, S.; Kim, S.-H. Enhancement of carbon monoxide mass transfer using an innovative external hollow fiber membrane (HFM) diffuser for syngas fermentation: Experimental studies and model development. Chem. Eng. J. 2012, 184, 268-277. [CrossRef]

13. Madigan, M.T.; Martinko, J.M.; Parker, J. Brock biology of Microorganisms; Prentice-Hall: Upper Saddle River, NJ, USA, 1997.

14. Orgill, J.J.; Atiyeh, H.K.; Devarapalli, M.; Phillips, J.R.; Lewis, R.S.; Huhnke, R.L. A comparison of mass transfer coefficients between trickle-bed, hollow fiber membrane and stirred tank reactors. Bioresour. Technol. 2013, 133, 340-346. [CrossRef] [PubMed] 
15. Younesi, H.; Najafpour, G.; Ku Ismail, K.S.; Mohamed, A.R.; Kamaruddin, A.H. Biohydrogen production in a continuous stirred tank bioreactor from synthesis gas by anaerobic photosynthetic bacterium: Rhodopirillum rubrum. Bioresour. Technol. 2008, 99, 2612-2619. [CrossRef] [PubMed]

16. Shen, Y.; Brown, R.; Wen, Z. Enhancing mass transfer and ethanol production in syngas fermentation of clostridium carboxidivorans p7 through a monolithic biofilm reactor. Appl. Energy 2014, 136, 68-76. [CrossRef]

17. Bredwell, M.D.; Worden, R.M. Mass-transfer properties of microbubbles. 1. Experimental studies. Biotechnol. Prog. 1998, 14, 31-38. [CrossRef] [PubMed]

18. Shen, Y.; Brown, R.; Wen, Z. Syngas fermentation of clostridium carboxidivoran p7 in a hollow fiber membrane biofilm reactor: Evaluating the mass transfer coefficient and ethanol production performance. Biochem. Eng. J. 2014, 85, 21-29. [CrossRef]

19. Liu, K.; Atiyeh, H.K.; Stevenson, B.S.; Tanner, R.S.; Wilkins, M.R.; Huhnke, R.L. Continuous syngas fermentation for the production of ethanol, n-propanol and n-butanol. Bioresour. Technol. 2014, 151, 69-77. [CrossRef] [PubMed]

20. Wikandari, R.; Youngsukkasem, S.; Millati, R.; Taherzadeh, M.J. Performance of semi-continuous membrane bioreactor in biogas production from toxic feedstock containing d-limonene. Bioresour. Technol. 2014, 170, 350-355. [CrossRef] [PubMed]

21. Youngsukkasem, S.; Akinbomi, J.; Rakshit, S.K.; Taherzadeh, M.J. Biogas production by encased bacteria in synthetic membranes: Protective effects in toxic media and high loading rates. Environ. Technol. 2013, 34, 2077-2084. [CrossRef] [PubMed]

22. Youngsukkasem, S.; Barghi, H.; Rakshit, S.; Taherzadeh, M. Rapid biogas production by compact multi-layer membrane bioreactor: Efficiency of synthetic polymeric membranes. Energies 2013, 6, 6211-6224. [CrossRef]

23. Youngsukkasem, S.; Rakshit, K.S.; Taherzadeh, M.J. Biogas production by encapsulated methane producing bacteria. Bioresources 2012, 7, 56-65.

24. Osuna, M.B.; Zandvoort, M.H.; Iza, J.M.; Lettinga, G.; Lens, P.N. Effects of trace element addition on volatile fatty acid conversions in anaerobic granular sludge reactors. Environ. Technol. 2003, 24, 573-587. [CrossRef] [PubMed]

25. Isci, A.; Demirer, G.N. Biogas production potential from cotton wastes. Renew. Energy 2007, 32, $750-757$. [CrossRef]

26. Langer, S.; Schropp, D.; Bengelsdorf, F.R.; Othman, M.; Kazda, M. Dynamics of biofilm formation during anaerobic digestion of organic waste. Anaerobe 2014, 29, 44-51. [CrossRef] [PubMed]

27. Youngsukkasem, S.; Chandolias, K.; Taherzadeh, M.J. Rapid bio-methanation of syngas in a reverse membrane bioreactor: Membrane encased microorganisms. Bioresour. Technol. 2015, 178, 334-340. [CrossRef] [PubMed]

(C) 2016 by the authors; licensee MDPI, Basel, Switzerland. This article is an open access article distributed under the terms and conditions of the Creative Commons by Attribution (CC-BY) license (http:/ / creativecommons.org/licenses/by/4.0/). 